LWSA

PAPER - OPEN ACCESS

\title{
Religiusitas pada Gay (Studi Fenomenologis)
}

\author{
Author : Josetta Maria Remila Tuapattinajaa \\ DOI $\quad: 10.32734 /$ lwsa.v1i1.144 \\ Electronic ISSN : :2654-7058 \\ Print ISSN : 2654-7066
}

Volume 1 Issue 1 - 2018 TALENTA Conference Series: Local Wisdom, Social and Arts

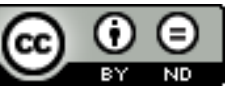

This work is licensed under a Creative Commons Attribution-NoDerivatives 4.0 International License.

Published under licence by TALENTA Publisher, Universitas Sumatera Utara
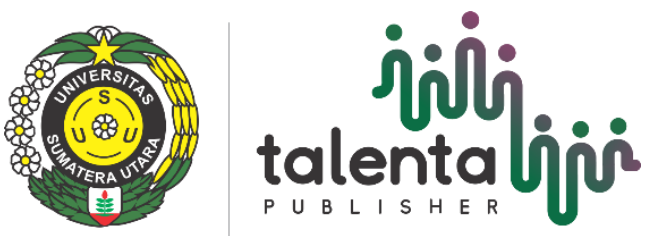


\title{
Religiusitas pada Gay (Studi Fenomenologis)
}

\author{
Josetta Maria Remila Tuapattinaja ${ }^{\mathrm{a}}$,Ariansyah ${ }^{\mathrm{a}}$ \\ ${ }^{a}$ Fakultas Psikologi, Universitas Sumatera Utara, Medan-20155, Indonesia \\ yosyetuapattinaja@gmail.com
}

\begin{abstract}
Abstrak
Eksistensi gay hingga saat ini masih menjadi hal yang kontroversial dan dipandang negatif di masyarakat Indonesia. Sebagian dari masyarakat menganggap tidak mungkin seorang gay memiliki religiusitas, tetapi sebagian lainnya percaya seorang gay juga memiliki religiusitas. Pendapat yang kontroversial ini mendorong peneliti melakukan penelitian untuk mengetahui bagaimana sebenarnya religiusitas yang dimiliki oleh seorang gay. Selain itu juga untuk mengetahui faktor-faktor yang menyebabkan seseorang menjadi gay, usia saat menyadari dirinya adalah gay, serta penghayatan mereka terhadap orientasinya. Penelitian ini menggunakan metode kualitatif fenomenologis, dengan partisipan 3 orang. Pengumpulan data dilakukan dengan wawancara mendalam. Analisis data dilakukan dengan pengkodingan, rekonstruksi data, dan merumuskannya. Hasil penelitian menunjukkan bahwa keimanan para partisipan tidak terpengaruh dengan kondisinya sebagai gay, serta tidak ada keinginan untuk jauh dari agama dan ibadah. Berkaitan dengan aspek keyakinan, partisipan yakin dengan kebenaran agama Islam, Al-Qur'an, nabi dan rasul, malaikat, hari kiamat, dan takdir. Tetapi pada aspek peribadatan, para partisipan sudah jarang ikut pengajian dan shalat dimesjid saat sudah menjalani kehidupan sebagai gay. Meskipun aspek pengetahuan para partisipan relatif sama, namun aspek pengalamannya menunjukkan adanya keraguan menjalankan ibadah (apakah akan diterima atau tidak), ada perasaan malu dan takut pada Allah. Pengamalan religiusitasnya menunjukkan adanya sikap berbohong pada orangtua terkait dengan orientasinya serta sulit untuk tinggalkan dunia gay. Faktor yang menyebabkan para partisipan menjadi gay adalah pengalaman negatif diusia sebelumnya. Menyadari diri sebagai gay berada pada rentang masa remaja. Penghayatan partisipan terhadap orientasinya sebagai gay secara umum memiliki kesamaan yaitu menganggapnya sebagai cobaan dari Allah, sama seperti orang-orang lain, yang diberi cobaan yang berbeda-beda.
\end{abstract}

Kata kunci: Kata kunci; religiusitas; gay

\section{Pendahuluan}

Menurut Glock dan Stark (dalam Dister, 1988), religiusitas merupakan unsur internalisasi agama ke dalam diri seseorang. Menurut Ancok \& Suroso (1994) terdapat lima dimensi dari religiusi tas yaitu pertama adalah dimensi keyakinan, bisa disebut sebagai akidah Islam menunjukkan keyakinan seorang muslim terhadap kebenaran ajaranajaran agama Islam, terutama terhadap ajaran-ajaran yang bersifat fundamental dan dogmatik. Kedua, dimensi peribadatan atau syariah menunjuk pada kepatuhan seorang muslim dalam mengerjakan kegiatan-kegiatan ritual sebagaimana yang diperintahkan oleh agama Islam. Ketiga, dimensi pengamalan atau akhlak, menunjukkan perilaku seorang muslim yang dimotivasi oleh ajaran-ajaran agama Islam, dalam berelasi dengan dunianya, terutama dengan manusia lain.Keempat, dimensi pengalaman atau penghayatan, menunjuk pada pengalaman seorang muslim dalam merasakan dan mengalami perasaan-perasaan dan pengalaman-pengalaman religius. Kelima, dimensi pengetahuan menunjuk pengetahuan dan pemahaman seorang muslim terhadap ajaran-ajaran agamanya, terutama mengenai 
ajaran-ajaran pokok dari agamanya. Menurut definisi dan dimensi tersebut berarti orang yang beragama memiliki religiusitas namun dengan tingkat yang berbeda- beda, tak terkecuali pada kaum gay yang beragama Islam.

Menurut Dede Oetomo (2001) seseorang dikatakan gay bila ia memiliki orientasi atau pilihan seks pokok atau dasarnya, entah diwujudkan ataupun tidak, diarahkan pada sesama jenis kelaminnya. Berarti seorang gay memiliki ketertarikan kepada pria, dan ketertarikan yang muncul tersebut semata-mata bukan hanya dalam hal perilaku seksual saja, melainkan juga yang masih berwujud emosional atau belum dilanjutkan ke dalam bentuk perilaku. Kartono (1989) mengatakan bahwa faktor-faktor yang menyebabkan seseorang menjadi gay berkaitan dengan herediter sebagai akibat dari adanya ketidakseimbangan hormon-hormon seks selama masa kehamilan Ibu, dengan lingkungan sebagai pengaruh buruk dari lingkungan yang membahayakan kematangan seksual yang normal. Bisa juga terkait dengan pengalaman di masa lalu, baik yang dengan adanya dorongan untuk mendapat kepuasan melalui hubungan dengan sesama gay karena pernah memiliki atau menghayati pengalaman dengan gay yang menggairahkan di masa lalu, maupun adanya pengalaman traumatis dengan ibu sehingga menimbulkan perasaan benci atau antipati terhadap ibunya dan akhirnya digeneralisasikan kepada seluruh wanita sehingga muncul dorongan menjadi gay yang menetap.

Di dalam penelitian ini, kami berasumsi bahwa pada dasarnya gay juga memiliki religiusitas. Sehubungan dengan asumsi tersebut, kami mencoba untuk mengeksplorasi religiusitas pada gay yang beragama Islam di setiap fase-fase tersebut. Melalui penelitian ini, kami berharap dapat memberikan bukti ilmiah tentang religiusitas pada gay yang beragama Islam sebelum dan di awal menyadari sebagai gay, serta saat ini sebagai gay, juga latar belakang pemilihan orientasi seksual seorang gay.

\section{Metode penelitian}

\subsection{Metode penelitian}

Metode yang digunakan adalah kualitatif dengan pendekatan fenomenologis, yaitu menekankan pada pengalaman seseorang dan bagaimana pengalaman tersebut diinterpretasi olehnya [14].

\subsection{Metode penelitian}

Pengambilan partisipan dalam penelitian ini menggunakan purposive sampling dan snowball sampling. Teknik purposive sampling maksudnya adalah partisipan dipilih sesuai dengan karakteristik yang sudah ditetapkan yaitu pria yang telah mengidentifikasi dirinya sebagai gay dan menganut agama Islam. Kemudian pengambilan partisipan dengan teknik snow ball sampling yaitu pengambilan partisipan dengan meminta informasi dari partisipan sebelumnya untuk mendapatkan partisipan selanjutnya [19].

\subsection{Metode penelitian}

Metode yang digunakan untuk mengumpulkan data adalah wawancara mendalam, dengan alat bantu berupa panduan wawancara dan alat perekam serta inform consent. Data yang dianalisa secara kualitatif dengan melakukan reduksi data, penyajian data dan verifikasi, penarikan kesimpulan.

\section{Hasil dan pembahasan}

\subsection{Factor yang melatar belakangi para partisan menjadi gay}

Faktor yang melatarbelakangi para partisipan menjadi gay adalah adanya pengalaman negatif di masa lalu. Partisipan pertama, Rudi, 22 tahun, seorang sarjana yang merupakan anak pertama dari tiga bersaudara, berasal dari keluarga berada, yang lebih dekat dengan ibu daripada bapak yang sering marah, memukul serta mengekang Rudi untuk lebih sering dirumah daripada bermain dengan teman-teman. Rudi termasuk anak yang cerdas sejak kecil sehingga sering di bully teman-temannya. Hingga usia 15 tahun, ia kemudian berkenalan dan dekat dengan seorang pria yang sangat perhatian terhadap dirinya, dan inilah awal munculnya perasaan suka terhadap pria tersebut yang 
kemudian berlanjut hingga menjadi teman dekat. Partisipan kedua, Hadi, bungsu dari 9 bersaudara keluarga petani merasa lebih dekat dengan ibu dan kakak-kakak daripada dengan ayah dan abang-abang yang ia nilai terlalu keras dan tegas. Ia pernah mengalami pelecehan seksual ketika masih SD oleh saudaranya sendiri yang umurnya jauh lebih tua darinya. Partisipasn ketiga adalah Willy, anak pertama dari tiga bersaudara, usia 23 tahun. Tidak dekat dengan bapak yang kadangkala bisa marah dengan keras tetapi disaat lain bias berperilaku baik. Lebih senang bermain dengan teman perempuan sejak SD karena tidak suka olahraga seperti teman laki-laki lainnya, tetapi saat itu juga ia sudah sangat suka melihat laki-laki tampan di televise hingga akhirnya, ia menyadari dirinya sebagai gay ketika ia mulai jatuh cinta kepada seorang laki-laki saat kelas 2 SMA.

\subsection{Religiusitas}

Dimensi pertama adalah keyakinan. Ketiga partisipan tidak mengalami perubahan dalam hal keyakinan akan keberadaan Allah SWT dan agama Islam yang paling benar, baik sebelum menyadari dirinya adalah seorang gay hingga saat ini telah mengidentifikasikan dirinya sebagai gay. Partisipan pertama, Rudi, sempat merasa kesal terhadap ajaran agamnya yang melarang gay, sedangkan partisipan kedua, Hadi, merasa kecewa karena dilahirkan sebagai gay. Tetapi kekesalan dan kekecewaan ini berangsur hilang ketika keyakinan akan kebenaran ajaran-ajaran agamanya kembali muncul saat menghadapi persimpangan, terutama yang bersifat fundamental dan dogmatik sudah menetap dalam dirinya [1].

Dimensi kedua adalah peribadatan. Ketiga partisipan secara keseluruhan menunjukkan kepatuhan mengerjakan kegiatan ritual wajib yang diperintahkan agama Islam saat belum menyadari dirinya adalah seorang gay. Tetapi ketika mulai menyadari dan menjalani kehidupan sebagai gay, partisipan pertama, Rudi, mulai sulit untuk khusyuk dalam ibadah karena ragu apakah ibadahnya akan diterima atau tidak. Partisipan kedua, Hadi, yang tadinya malas mengerjakan shalat justru makin sering berzikir dan mengikuti pengajian saat merasa dirinya seorang gay dengan harapan ibadah dapat menghindarkan dirinya dari berpikiran dan berperilaku negatif. Tetapi ketika ia telah mengidentifikasikan dirinya sebagai gay, ia sibuk dengan sosial media, shalat wajib mulai sering ditinggalkan dan sudah tidak pernah mengikuti pengajian.

Dimensi pengamalan adalah dimensi yang ketiga dari religiusitas menunjukkan bahwa ketiga partisipan sebelum menyadari dirinya seorang gay adalah suka menolong teman, mudah dalam meminta dan memberi maaf, serta memegang amanah. Hanya saja setelah mengidentifikasikan diri sebagai gay, pengalaman suka menolong teman masih tetap ada tetapi sudah mulai terbiasa berbohong pada orangtua untuk menutupi orientasinya serta sulit untuk meninggalkan dunia gay, dan sulit untuk menjalankan perintah shalat lima waktu apalagi untuk menjalaninya di mesjid.

Dimensi keempat adalah dimensi pengalaman. Ketiga partisipan memiliki beberapa pengalaman yang membuat mereka merasakan kedekatan dengan Allah SWT sebelum menyadari keadaan sebagai gay. Partisipan pertama, Rudi, sebelum menyadari dirinya sebagai gay mudah tergetar ketika mendengarkan ayat-ayat Al-Qur'an dilantunkan dengan indah setelah sembuh dari kecelakaan yang ia nilai sebagai keajaiban dari Allah SWT. Begitu juga dengan partisipan kedua, Hadi, merasa nyaman dekat dengan Allah SWT setelah mengalami teguran dari Allah SWT melalui kecelakaan saat ia melawan orangtua. Sedangkan partisipan ketiga, Willy, selalu merasa tergetar ketika melihat keindahan alam dan selalu bersyukur saat merasakan pertolongan Allah SWT ketika doanya terkabul. Saat menyadari dirinya adalah seorang gay, muncul pemikiran bahwa keberadaannya sebagai gay adalah cobaan dari Allah SWT dan yakin akan ada hikmah dibalik orientasinya ini. Adanya larangan gay di dalam agama tidak membuatnya menjauh dari Tuhan dan agama. Tetapi di sisi lain, ada keraguan dalam diri apakah ibadah seorang gay diterima atau tidak, ibadahnya juga menjadi kurang khusyuk dan sudah jarang mencurahkan isi hatinya kepada Allah SWT.

Dimensi yang kelima dari religiusitas adalah pengetahuan. Hasil yang diperoleh dari penelitian ini menunjukkan bahwa pengetahuan dan pemahaman partisipan terhadap ajaran-ajaran agamanya, terutama mengenai ajaran-ajaran pokok dari agamanya secara keseluruhan relatif sama dan tidak terlihat perubahan saat sebelum menyadari dirinya 
sebagai gay hingga saat ini sudah mengidentifikasikan dirinya sebagai gay. Memang ada perbedaan dalam detail pengetahuan dan pemahaman tetapi tidak berbeda secara signifikan.

\section{Hasil penelitian}

Hasil penelitian ini menunjukkan bahwa pada diri ketiga partisipan terdapat religiusitas dengan gambaran yang berberda-beda. Artinya, sebagai gay, mereka tidak ingin menjauh dari Tuhan dan agama serta antara dimensi yang satu dengan yang lainnya saling mempengaruhi. Tidak adanya perubahan signifikan dalam dimensi pengetahuan, bahkan ada upaya untuk lebih dekat dengan Allah SWT agar dapat terhindar dari pemikiran dan perbuatan negatif menunjukkan bahwa dimensi pengetahuan yang dimiliki juga mendukung dimensi keyakinan. Baiknya dimensi pengetahuan dan keyakinan yang dimiliki juga bisa meningkatkan dimensi peribadatan. Begitu juga dengan dimensi pengamalan dapat meningkatkan dimensi pengalaman pada diri mereka. Pada ketiga partisipan secara umum terlihat pengetahuan dan pendidikan agama yang mereka dapatkan sejak kecil membuat keyakinan mereka kepada Allah SWT tetap bertahan, dan hal ini membuat mereka mau menjalankan ibadah meskipun ada perasaan ragu, malu dan kesal dalam diri. Keadaan sebagai seorang gay juga tidak menghalangi mereka untuk mengamalkan ajaran agama seperti berbuat baik kepada orang lain, dan dengan melakukan hal tersebut maka mereka dapat merasakan kepuasan setelah berbuat baik dan merasa dekat dengan Allah SWT. Hanya saja, saat ini partisipan mulai terbiasa berbohong pada orangtua untuk menutupi keberadaan mereka sebagai gay, apalagi saat ini para partisipian sudah merasa sulit untuk meninggalkan dunia gay dan berpikir bahwa keberadaannya ini adalah cobaan dari Allah SWT, sama seperti keberadaan orang-orang lain yang juga diberi cobaan oleh Allah SWT.

\section{Kesimpulan}

Penelitian ini menunjukkan bahwa secara umum, keadaan mereka sebagai seorang gay tidak mempengaruhi keimanan dan menganggap bahwa dengan mendekatkan diri kepada Allah maka dapat menghindarkan diri dari pemikiran dan perbuatan negatif. Semua partisipan tidak memiliki keinginan untuk menjauh dari agama meskipun tahu bahwa gay menjadi hal yang dipermasalahkan dalam agama Islam. Partisipan yakin dengan kebenaran agama Islam, Al-Qur'an, nabi dan rasul, malaikat, hari kiamat, dan takdir. Tetapi saat sudah mengidentifikasikan diri sebagai gay, para partisipan sudah jarang ikut pengajian dan shalat dimesjid. Meskipun aspek pengetahuan para partisipan relatif sama, namun aspek pengalamannya menunjukkan adanya keraguan menjalankan ibadah (apakah akan diterima atau tidak), ada perasaan malu dan takut pada Allah. Sedangkan pengamalan religiusitasnya masih ada sikap berbohong pada orangtua akan orientasinya yang sulit untuk meninggalkan dunia gay.

Faktor yang menyebabkan para partisipan menjadi gay adalah pengalaman negatif negatif di masa lalu, baik terkait dengan adanya pelecehan seksual yang di alami di usia sekolah, sulit bergaul dengan teman sejenis dan lebih tertarik untuk berteman dekat dengan sesama jenis yang dinilai lebih mengerti dan perhatian terhadap dirinya. Ketiga partisipan menyadari diri sebagai gay pada saat masih usia remaja dan penghayatan orientasinya sebagai gay secara umum memiliki kesamaan yaitu menganggapnya sebagai cobaan dari Allah, sama seperti orang-orang lain, yang diberi cobaan yang berbeda-beda.

Implikasi dari penelitian ini secara teoritis dapat menambah wacana berkaitan dengan keberadaan seorang gay dan religiusitasnya sehingga mendapatkan pemahaman yang komprehensif dan juga sebagai bahan referensi bagi para peneliti selanjutnya. Secara aplikatif, mengajak para gay yang beragama Islam untuk lebih meningkatkan pemahaman tentang ajaran-ajaran agama agar memiliki pemahaman yang benar tentang maksud pengajaran Allah SWT tentang keberadaannya saat ini dan maksud penciptaan-Nya, serta dapat terhindar dari rasa malu dan takut akan Allah SWT sehingga dapat lebih khusyuk dalam beribadah.

Rekomendasi yang dapat diberikan untuk peneliti selanjutnya adalah mengkaitkan aspek religiusitas dengan self concept, self esteem dan forgiveness terkait dengan adanya pengalaman negatif di masa lalu. Hal ini mengingat dasar atau pengalaman awal ketertarikan terhadap sesama jenis pada penelitian ini adalah adanya pengalaman negatif yang tidak menyenangkan dengan figur bapak dan pernah mengalami pelecehan seksual. 


\section{Referensi}

[1] Ancok, D., \& Suroso, F.N. (1994). Psikologi Islami. Pustaka Pelajar, Yogyakarta

[2] Boellstorff, Tom. (2010). Antara agama dan hasrat : muslim yang gay di Indonesia. Jurnal Gandrung (1), 91

[3] D‘Augelli, A. R. (1994). - Identity Development and Sexual Orientation: Toward a Model of Lesbian, gay, and Bisexual Development. ॥ In E. J. Trickett, R. J. Watts, and D. Birman(eds.), Human Diversity: Perspectives on People in Context.San Francisco: Jossey-Bass

[4] De Grave, Eduard. (2010). Praktek Homoseksual di Pondok Pesantren. http://annunaki.me. [Diakses pada 23 Juni 2014]

[5] Dister, N.S. (1988). Psikologi Agama. Kanisius, Yogyakarta

[6] Doel. (2014). Berbagi dan Berbuka Puasa Bersama di Panti Asuhan. http://gayindonesia.net. [Diakses pada 3 Juni 2015]

[7] Dzulkarnain, Iskandar. (2011). Perilaku Homoseksual di Pondok Pesantren. Thesis. Fakultas Sosiologi. Universitas Gadjah Mada

[8] Feldmen, R.S. (1990). Understanding Psychology, 2 ed.. McGraw- Hill Publishing Company, New York

[9] Hamali, Syaiful. (2013). Konflik dan keraguan individu dalam perspektif psikologi agama. Jurnal Al-Adyan (8), 27

[10] Kartono, K. (1989). Psikologi Abnormal dan Abnormalitas Seksual. Mandar Maju, Bandung

[11] Kendall, P.C. (1998). Abnormal Psychology Human Problems Understanding. 2 ed . Houghton Mifflin Company, Boston

[12] Madjid, R. (1997). Islam Kemoderenan dan Ke-Indonesiaan. Mizan Pustaka, Bandung

[13] Mangunwijaya, Y. B. (1986). Menumbuhkan Sikap Religiusitas Anak. Gramedia, Jakarta

[14] Moleong, Lexy.J. (2007). Metodologi Penelitian Kualitatif. PT. Remaja Rosdakarya Offset, Bandung

[15] Nugroho, S.C.,Siswati, Dra. Msi, dan Sakti, Dra.H.M.Kes. Pengambilan Keputusan Menjadi Homoseksual pada Laki-Laki Usia Dewasa Awal

[16] Oetomo, D. (2001). Memberi Suara Pada Yang Bisu. Galang Press, Yogyakarta

[17] Okdinata. (2009). Religiusitas Kaum Homoseks (Studi Kasus Tentang Dinamika Psikologis

[18] Keberagamaan gay Muslim Di Yogyakarta. Skripsi. Fakultas Psikologi. Universitas Islam Negeri Sunan Kalijaga Yogyakarta

[19] Poerwandari, E.K. (2007). Pendekatan Kualitatif untuk Penelitian Perilaku Manusia. Lembaga Pengembangan Sarana Pengukuran dan Pendidikan Psikologi, Depok

[20] Rangkuti, R.S. (2012). Homoseksual dalam Perspektif Hukum Islam. Jurnal Ilmu Syari'ah dan Hukum (46), 11-12

[21] Sabiq, Sayyid. (1981). Fiqh al-Sunnah. Dar Al-Fikr, Libanon

[22] Syam, Ramadon. (2009). Homoseksual di Mata Psikologi. http://ruangpsikologi.com. [Diakses pada 5 Juni 2014]. 